\title{
Pengenalan Teknologi Telekomunikasi pada Generasi Muda dalam Menyongsong Era Baru Teknologi Generasi Kelima (5G)
}

\author{
Bengawan Alfaresi", Feby Ardianto, Muhammad Hurairah, Taufik Barlian, Rika Noverianty \\ Program Studi Teknik Elektro, Fakulas Teknik, Universitas Muhammadiyah Palembang, Indonesia.
}

\author{
Article history \\ Received: 29-06-2020 \\ Revised: 03-07-2020 \\ Accepted: 07-07 2020 \\ *Corresponding Author: \\ Bengawan Alfaresi \\ Program Studi Teknik Elektro, \\ Fakultas Teknik, Universitas \\ Muhammadiyah Palembang \\ Palembang \\ Email: \\ begawan_alfarezi@um- \\ palembang.ac.id
}

Abstract: The development of telecommunications technology has developed very rapidly. This is in line with the increase in internet data traffic which is growing tremendously. The use of the Internet has been used in all layers of the age segment both the older generation to the younger generation. Global competition in the future is very tight and required knowledge of technology, especially telecommunications technology. This is the basis of community service activities for young people to be given knowledge and education about telecommunications technology and its development and to prepare young people to welcome the $5 \mathrm{G}$ era to have competitiveness to face the competition map going forward. In this dedication activity, the method used is direct material exposure to students with the implementation of pre and post-tests as material for evaluating activities. Community service activities carried out in Palembang Muhammadiyah 6 Junior High School with a duration of community service activities for 1 day. The number of students who took part in the service was 60 people. In this service, it was found that almost all students have used the Internet with various uses both in the use of email, social media and social messenger, where Facebook is the most favorite social media for junior high school students. From the results of the pre and posttest evaluation, it was found that the level of student retention regarding telecommunications has increased.

Keywords: internet; technology; competitiveness; e-mail; social media

Abtrak: Perkembangan teknologi telekomunikasi telah berkembang sangat pesat. Hal ini selaras dengan peningkatan traffic data internet yang tumbuh luar biasa. Penggunaan Internet telah digunakan pada semua lapisan segmen umur baik generasi tua sampai generasi muda. Persaingan global ke depan sangat ketat dan diperlukan pengetahuan tentang teknologi khususnya teknologi telekomunikasi. Hal tersebut yang mendasari dilakukannya kegiatan pengabdian masyarakat kepada para generasi muda untuk diberikan pengetahuan dan edukasi mengenai teknologi telekomunikasi dan perkembangannya serta mempersiapkan para generasi muda untuk menyongsong era 5G agar memiliki daya saing untuk menghadapi peta persaingan ke depan. Pada kegiatan pengabdian ini, metode yang digunakan yaitu pemaparan materi secara langsung kepada siswa dengan pelaksanaan pre dan posttest sebagai bahan evaluasi kegiatan. Kegiatan pengabdian masyarakat dilaksanakan di SMP Muhammadiyah 6 Palembang dengan durasi kegiatan pengabdian masyarakat selama 1 hari. Jumlah siswa yang mengikuti pengabdian tersebut sejumlah 60 orang. Pada kegiatan pengabdian ini didapatkan bahwa hampir seluruh siswa telah menggunakan Internet dengan berbagai penggunaan baik dalam penggunaan email, media sosial maupun social messanger, dimana Facebook merupakan media social yang paling favorit pada siswa SMP. Dari hasil evaluasi 
pre dan post tes yang dilakukan didapatkan bahwa tingkat pemahan siswa tentang telekomunikasi mengalami peningkatan.

Kata Kunci: internet; teknologi; daya saing; e-mail; media sosial

\section{PENDAHULUAN}

Perkembangan teknologi telekomunikasi terus mengalami perkembangan yang sangat pesat. Teknologi telekomunikasi mulai berkembang sejak Generasi pertama (1G) pada awal tahun 1990 dan dalam tempo 20 tahun terus mengalami perkembangan sampai dengan teknologi telekomunikasi generasi keempat (4G) yang dapat kita nikmati saat ini. Indonesia sampai saat ini masih tahap persiapan untuk menyongsong teknologi 5G ke depan. (Admaja, 2018). Dalam beberapa tahun terakhir, telah terjadi peningkatan lalu lintas data Internet yang sangat pesat (Kristem et al., 2018) Hal ini dikarenakan perkembangan smartphone, hadphone yang cukup significant karena operator dan vendor berusaha meningkatkan layanan seiring dengan permintaan yang terus meningkat. (Majed et al., 2018). Hal ini menunjukkan bahwa tingkat ketergantungan masyarakat dunia terhadap Internet semakin meningkat. Saat ini internet telah diletakkan diposisi yang sangat penting dalam kehidupan bermasyarakat.

Di Indonesia, penggunaan internet telah berkembang luar biasa. Berdasarkan survey yang dilakukan oleh APJII (Asosiasi Penyelenggara Jasa Internet Indonesia) menunjukkan bahwa pada 2017, pengguna internet di Indonesia mancapai 143,26 juta atau sekitar 54,68\% dari seluruh warga negara Indonesia, sedangkan pada 2018 mengalami peningkatan mejadi 171.17 juta atau sekitar $64,8 \%$. Hal ini menunjukkan bahwa pada penggunaan teknologi telekomunikasi khususnya internet telah digunakan secara masive oleh masyarakat Indonesia. Peta penyebaran penggunaan teknologi internet telah merata di semua pulau di Indonesia dengan Jawa merupakan pulau yang paling banyak mencapai $55.7 \%$ sedangkan pulau sumatera berada di posisi nomer dua yaitu dengan kontribusi penggunaan internet mencapai $21.6 \%$. Dari peta penggunaan internet di wilayah sumatera, provinsi sumatera utara merupakan provinsi dengan penggunaan Internet tertinggi mencapai $6.3 \%$ dan provinsi Sumatera Selatan berada di posisi nomer dua yaitu dengan 3\%. Masih berdasarkan survey ooleh APJII menyatakan bahwa penetrasi penggunaan Internet di Sumatera Selatan mencapai $64.4 \%$ dari total masyarakat.(APJII, 2018)

Dalam menghadapi peta persaingan global, generasi muda harus dipersiapkan dalam hal pengetahun telekomunikasi perkembangannya dan aplikasinya. Alasan utama dari diperlukannya kegiatan pengabdian kepada masyarakat pada generasi muda ini karena berdasarkan penelitian dihasilkan bahwa pada tahun 2018, segmet umur dengan pengguna Internet tertinggi yaitu pada segment umur 15-19 tahun yaitu mencapai $91 \%$ dari jumlah populasi di segment tersebut. Sedangkan pada segmen umur 10-14 tahun mencapai 66.2\% dari total keseluruhan populasi di segmen tersebut. Sehingga kegiatan pengabdian yang kami lakukan dirasa sangat penting dalam mempersiapkan generasi muda ke depan.(APJII, 2018)

Peta persaingan ke depan segala sesuatu terhubung pada Internet atau yang disebut dengan IoT (Internet of Things). Mulai dari smart home, smart city, smart car dan lain-lain sangat bergantung pada kualitas Internet. Internet yang baik membutuhkan Throughput yang cepat dan latency yang kecil (Majed et al., 2018). Hal tersebut merupakan tantangan teknologi ke depan dalam upaya menyokong dalam peta persaingan global. Teknologi $5 \mathrm{G}$ hardir untuk menjawab segala permasalahan ke tersebut. 
Saat ini Indonesia sudah ketinggalan dalam implementasi teknologi 5G. Indonesia saat ini masih mempersiapakan regulasi dan spektrum frekuensi yang digunakan dalam implementasi teknologi 5G. Saat ini seluruh operator di tanah air telah melakukan trial teknologi 5G dalam upaya mempersiapkan diri dalam penggelaran jaringan. Frekuensi yang berpeluang digunakan pada teknologi $5 \mathrm{G}$ di Indonesia yaitu pada frekuensi middle band. Hal ini dikarenakan pada frekuensi tersebut memilki coverage layanan yang sedang (tidak terlalu kecil seperti frekuensi high band) dan memilki pita frekuensi dengan band yang luas (tidak seperti pada frekuensi low band). Negara yang telah menggunakan frekuensi middle band untuk implementasi teknologi 5G yaitu Amerika, Inggris, Jerman dan juga China (Qualcomm, 2019). Indonesia diprediksi mulai menggelar jaringan 5G pada tahun 2022 dan siap dipergunakan sebelum tahun 2024.

Kegiatan pengabdian kepada masyarakat mengenai Pengenalan teknologi 5G pernah dilakukan oleh tim Teknik Elektro Universitas Mercubuana kepada siswa SMA di kembangan Utara. Pada pengabdian tesebut lebih berfokus pada sistem antenna yang mendukung teknologi 5G ke depan (Firdausi, 2019). Pada pengabdian masyarakat yang dilakukan oleh tim Teknik Elektro Universitas Muhammadiyah Palembang lebih menekankan pada awal mula teknologi telekomunikasi, perkembangannya serta gambaran teknologi telekomunikasi di masa depan yang akan menyambut hadirnya teknologi 5G disertai dengan perkembangan aplikasi yang berkembang dari tiap-tiap generasi telekomunikasi. Sasaran yang kita ingin dicapai yaitu pada siswa menengah pertama di SMP Muhammadiyah 6 Palembang.

\section{METODE}

Kegiatan pengabdian masyarakat yang dilangsungkan dengan menggunakan metode pemaparan materi secara langsung kepada siswa. Pada kegiatan pengabdian dibagi menjadi tiga tahapan utama yaitu tahapan persiapan, tahapan pelaksanaan pengabdian dan tahapan evaluasi.

1. Tahap Persiapan

Pada tahap ini dilaksanakan persiapan mulai dari persiapan daftar hadir, persiapan questioner, persipaan doorprize, persiapan pelaksanaan

2. Tahap pelaksanaan pengabdian

Berupa kegiatan seminar kepada siswa-siswi SMP Muhammadiyah 6 Palembang. Beberapa langkah yang dilakukan dalam kegiatan ini yaitu:

a. Pengisian daftar hadir: Pada langkah ini, sebagai sarana untuk mengetahui jumlah siswa yang ikut berpartisipasi dalam kegiatan pengabdian masyarakat

b. Pengisian biodata email dan akun : Pada langkah ini, sebagai media untuk mengetahui tingkat keaktifan dan karakteristik siswa terhadap dunia Internet

c. Pengisian kuesioner awal (pre-test): Pada langkah ini, sebagai media untuk mengetahui seberapa paham siswa terhadap teknologi telekomunikasi sebelum dilakukan seminar

d. Penyampaian materi: Kegiatan ini sebagai sarana pembelajaran terhadap siswa tentang teknologi telekomunikasi dan merupakan inti dari kegiatan pengabdian masyarak ini

e. Pemberian doorprize: Langkah ini adalah inisiatif dari pelaksana pengabdian masyarakat, sebagai sarana penghargaan terhadap siswa agar sebagai motivasi untuk terus belajar ke depannya

f. Pengisian kuesioner akhir (post-test): Pada langkah ini, sebagai media untuk mengetahui seberapa paham siswa terhadap teknologi telekomunikasi setelah dilakukan seminar 
3. Tahap Evaluasi Akhir

Untuk melakukan evaluasi dari kegiatan pengabdian masyarakat ini, maka diperlukan langkah-langkah sebagai berikut:

a. Analisa hasil kegiatan: Dari data-data yang dihasilkan dalam kegiatan pengabdian masyarakat tersebut, dianalisa mengenai jumlah kehadiran peserta, karakteristik siswa, tingkat pengetahuan siswa tentang telekomunikasi dan analisa hasil dari kegiatas tersbut dari kuesioner.

b. Penarikan kesimpulan dari kegiatan: Dari hasil analisa tersebut, didapatkan value pada tiap-tiap parameter yang telah dianalisa.

\section{HASIL DAN PEMBAHASAN}

Kegiatan pengabdian masyarakat dilaksanakan di SMP Muhammadiyah 6 Palembang. Durasi kegiatan pengabdian masyarakat selama 1 hari. Kegiatan pengabdian dilaksanakan oleh tim PS Teknik Elektro Universitas Muhammadiyah 6 Palembang yang berjumlah 5 orang dosen. SMP Muhammadiyah 6 Palembang mengikutsertakan seluruh siswa kelas VII terdiri dari 2 kelas yaitu kelas-A dan kelas-B. Jumlah siswa yang mengikuti kegiatan pengabdian kepada masyarakat berjumlah 60 siswa.

Sebelum kegiatan pengabdian dimulai, siswa harus mengisi daftar hadir yang telah disiapkan oleh Tim pengabdian. Selain daftar hadir juga siswa diinstruksikan untuk mengisi biodata yang berisi email masing-masing siswa, akun media sosial (jika siswa telah memilki akun) dan juga akun social messanger (jika siswa telah memiliki). Hal ini bertujuan untuk meneliti tingkat penggunaan media internet oleh siswa SMP dan juga tingkat eksistensi siswa SMP terhadap update perkembangan aplikasi Internet yang digunakan.

Kegiata pengabdian dimulai dengan melakukan pre-test kepada seluruh siswa untuk mengetahui tingkat pengetahuan siswa terhadap teknologi Internet. Setelah pengisian tersebut dilakukan, dilanjutkan dengan pemaparan oleh Tim pengabdian mengenai kesiapan masyarakat dalam menyambut teknologi generasi 5G. Kegiatan pengabdian dapat dilihat pada gambar 1 .
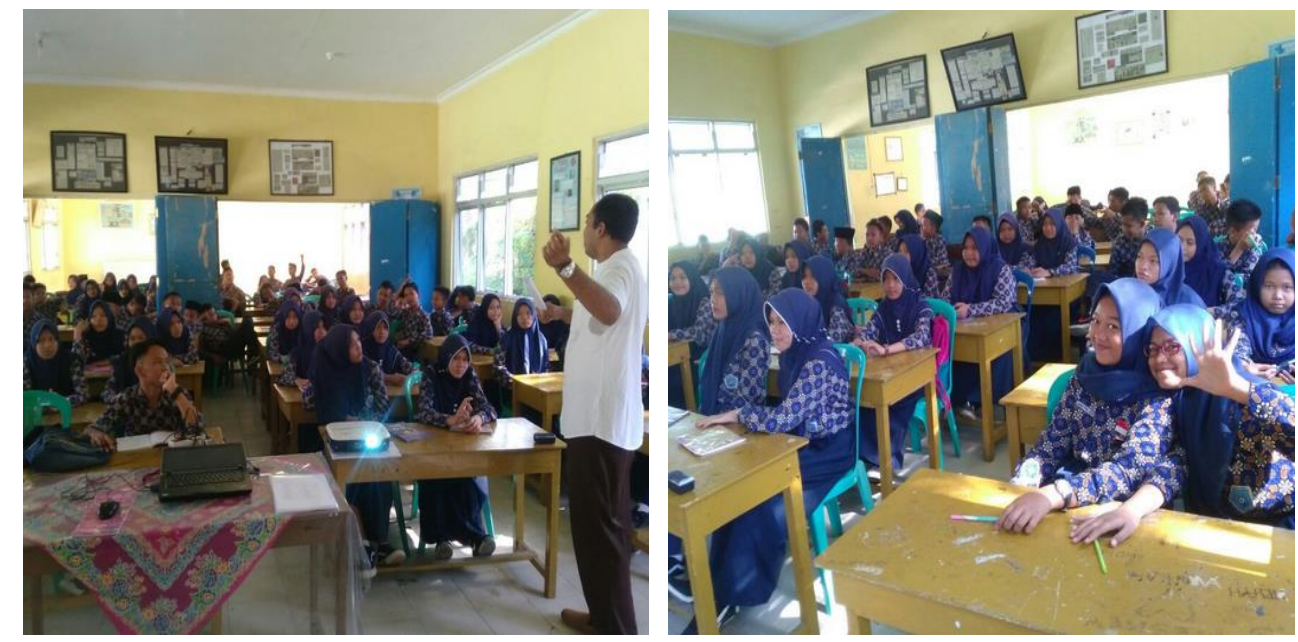

Gambar 1. Pemaparan Materi Pengenalan Teknologi Telekomunikasi menuju Generasi 5G 
Pemaparan dimulai dengan menjelaskan mengenai sejarah teknologi telekomunikasi mulai dari Generasi pertama sampai denga generasi yang sedang kita nikmati saat ini yaitu teknologi Generasi Keempat (4G). Dalam pemaparan tersebut dibahas mengenai perbedaan teknologi serta layanan yang dapat dinikmati di tiap-tiap generasi dan perbedaanya. Pemaparan dilanjutkan dengan perkembangan aplikasi baik itu media sosial maupun social messanger yang tumbuh di tiap-tiap generasi. Pembahasan terakhir yaitu menjelaskan mengenai teknologi telekomunikasi ke depan yaitu Generasi kelima (5G) serta kesiapan masyarakat dalam menyambut perkembangan teknologi tersebut. Tujuan dari materi tersebut yaitu menyiapkan generasi muda khususnya siswa SMP untuk mengetahui perkembangan dan update teknologi yang terus berkembang, serata mempersiapkan diri mereka dalam menghadapi perkebangan teknologi telekomunikasi khususnya Internet yang begitu pesat. Setelah pemaparan selesai, untuk memeriahkan acara tim pengabdian telah mempersiapkan door-prize dengan memberikan beberapa pertanyaan yang berhubungan dengan materi yang telah disampaikan. Tahapan terakhir dari pengabdian yaitu pengisian post test untuk mengetahui tingkat pemahaman siswa terhadap materi yang telah disampaikan.

Dari kegiatan pengabdian yang telah dilakukan, didapatkan empat pembahasan utama baik dari list daftar biodata akun maupun questioner pre-test dan post-test. Pembahasan utama tersebut yaitu mengenai analisa tingkat penggunaan email pada siswa SMP, analisa tingkat penggunaan aplikasi social media pada kalangan siswa SMP, analisa tingkat penggunaan aplikasi social messanger pada siswa SMP dan Analisa pengaruh pelaksanaan pengabdian terhadap pengetahuan siswa pada teknologi telekomunikasi.

\section{Analisa Tingkat Penggunaan Email pada Siswa SMP}

Email atau electronic mail merupakan salah satu aplikasi pada jaringan telekomunikasi yang berfungsi untuk mengirimkan pesan dari satu orang ke orang lain (baik satu orang maupun lebih). Email digunakan dengan menggunakan media Internet bisa dilakukan dengan menggunakan HP maupun komputer. Hasil dari pengisian biodata Internet pada siswa SMP Muhammadiyah 6 Palembang didapatkan hasil pada Gambar 2.

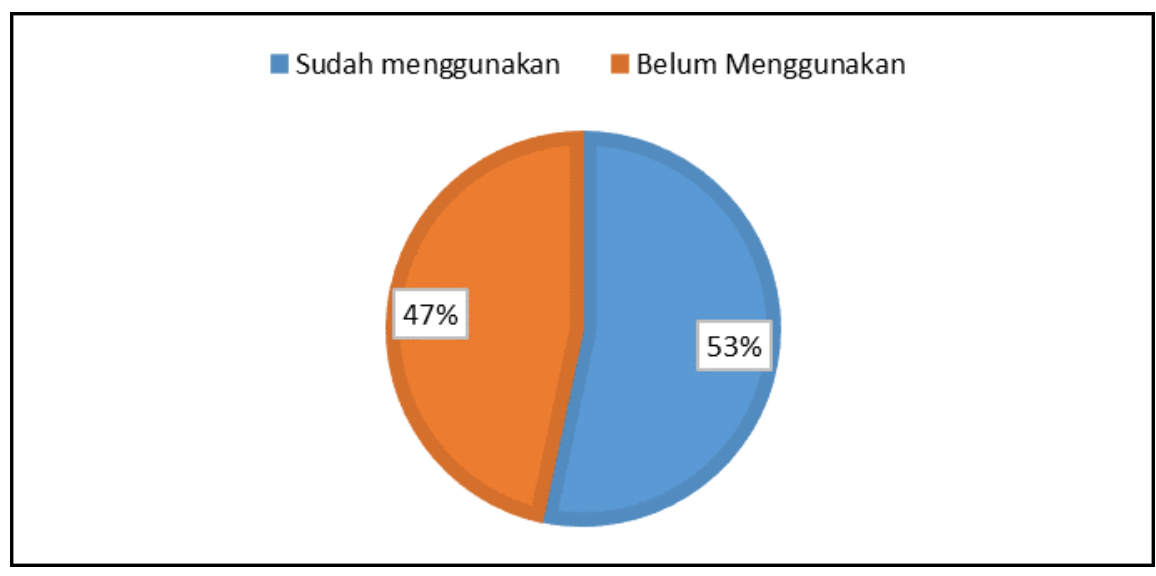

Gambar 2. Tingkat penggunaan Email pada kalangan Siswa SMP

Hasil yang didapatkan menunjukkan bahwa total mahasiswa yang mengisi daftar email pada pengabdian di SMP Muhammadiyah 6 Palembang sebanyak 60 siswa. Dari 60 siswa tersebut 
menunjukkan bahwa28 siswa atau sekitar 47\%siswa menyatakan belum memilki email sedangkan 32 atau sebesar 53\% siswa telah memilki email. Hal ini menunjukkan bahwa generasi muda saat ini khususnya siswa SMP Muhammadiyah 6 Palembang telah mengenal penggunaan media komunikasi khususnya email. Email sudah menjadi suatu identitas maupun alamat virtual dari seseorang.

\section{Analisa Tingkat Penggunaan Media Sosial pada Siswa SMP}

Social Media adalah sebuah media online, dengan para penggunanya bisa dengan mudah berpartisipasi, berbagi, dan menciptakan isi. Dengan menggunakan social media, kita bisa berinteraksi dengan dengan teman maupun kelompok teman di belahan dunia yang lain. Dalam pengabdian yang dilakukan menggunakan 3 macam media sosial sebagai parameter yang dianalisa yaitu facebook, Instagram dan Twitter.

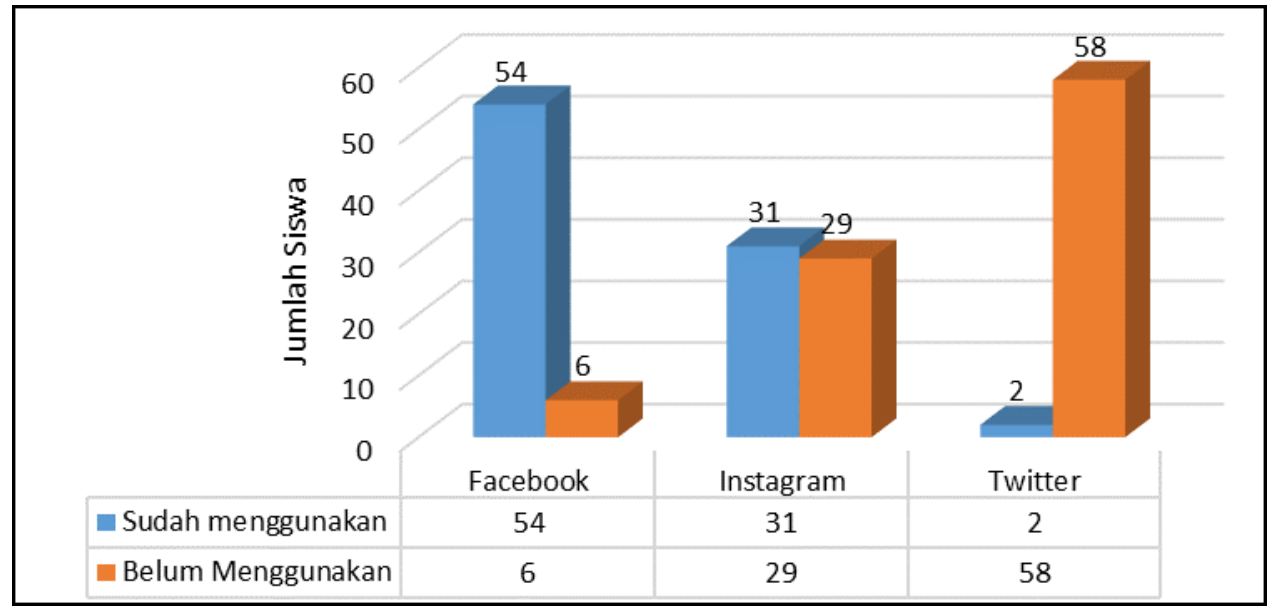

Gambar 3. Distribusi Siswa terhadap Penggunaan Social Media

Dari hasil biodata yang telah diisi oleh siswa SMP Muhammadiyah 6 Palembang menunjukkan bahwa untuk social media facebook menempati posisi pertama yang paling populer dikalangan generasi muda yaitu hampir 54 siswa atau sekitar $90 \%$ dari keseluruhan siswa telah memiliki akun facebook atau telah menggunakan facebook sebagai media Interaksi dengan teman dan masyarakat sekitar. Sedangkan hanya 6 siswa atau sekitar $10 \%$ siswa yang belum memiliki akun facebook atau dengan kata lain belum menggunakan facebook. Untuk sosial media instagram menempati posisi kedua yaitu dengan tingkat penggunaannya mencapai $51.67 \%$ atau sejumlah 31 siswa telah memiliki akun Instagram atau sudah menggunakan Instagram sebagai media Interaksi ke luar. Sedangkan $48.33 \%$ atau 29 siswa yang belum memiliki akun instagram atau dengan kata lain belum menggunakan instagram. Untuk social media twitter menempati posisi ketiga yaitu dengan tingkat penggunaan yang hanya $3.33 \%$ atau hanya 3 siswa yang memiliki akun twitter atau sudah menggunakan twitter sebagai media komunikasi interaksi dengan orang lain. Sedangkan hampir 96.67\% atau 58 siswa yang belum memiliki akun twitter atau dengan kata lain belum menggunakan twitter.

Dari data diatas menunjukkan bahwa hampir seluruh siswa di SMP Muhammadiyah 6 Palembang sudah sangat familiar terhadap social media dimana sosial media facebook merupakan sosial media yang paling favorit digunakan oleh siswa dalam berinteraksi didunia Internet. Hal ini karena media facebook merupakan salah satu jejaraing sosial terbesar di sunia sehingga sangat memudahkan seorang pengguna untuk membangun relasi dan juga jaringan. Dengan jaringan yang luas, facebook juga cocok digunakan sebagai tempat bisnis online. Tampilan yang mudah sangat mudah dan minimalis, serta aksesbilitas yang mudah, menyebabkan facebook dijakadikan sebagai favorit media social yang ada di masyarakat khususnya siswa SMP Muhammadiyah 8 Palembang. 
Analisa Tingkat Penggunaan Social Messanger pada Siswa SMP

Social messanger merupakan suatu aplikasi yang berfungsi untuk komunikasi antar sesama dengan menggunakan media Inernet. Pada penelitian ini membandingkan 3 aplikasi social messanger yaitu Whatssappp, line dan BBM.

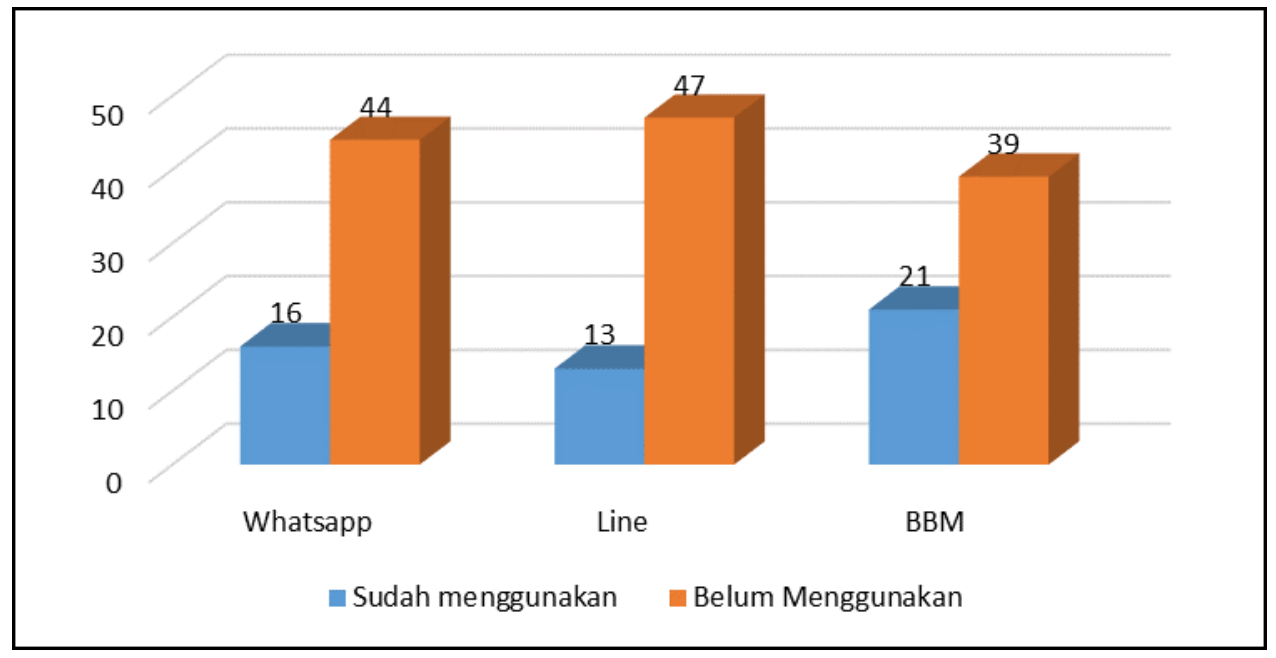

Gambar 4. Distribusi Siswa terhadap Penggunaan Social Media

Dari gambar.4 menunjukkan bahwa untuk social messanger whatsapp, sekitar $26.67 \%$ atau sekitar 16 siswa telah menggunakan whatssapp sebagai media komunikasi jarak jauh untuk berhubungan dan pertukaran informasi dengan sesama. Sedangkan $73.33 \%$ atau 44 siswa belum menggunakan whatsapp. Sedangkan untuk social messanger LINE, sekitar $21.67 \%$ atau 13 siswa telah menggunakan LINE sebagai media komunikasi jarak jauh untuk berhubungan dan pertukaran informasi dengan sesama. Sedangkan $78.33 \%$ atau 47 siswa yang belum menggunakan LINE. Untuk social messanger BBM menunjukkan bahwa sekitar 35\% atau 21 siswa yang menggunakan BBM sebagai media komunikasi sosialnya. Sedangkan hampir $65 \%$ atau 39 siswa yang belum menggunakan BBM. Hal ini juga menunjukkan bahwa dalam penggunaan social messanger tidak ada

\section{Evaluasi pelaksanaan pengabdian terhadap penyampaian Materi}

Pada tahapan ini dilakukan analisa mengenai pelaksanaan pengabdian yaitu dengan menganalisa hasil dari questioner yang telah disebar dan diisi oleh siswa pada waktu awal (pre-test) dan akhir pelaksanaan (post-test). Banyaknya kategori yang digunakan menggunakan rumus dibawah:

$$
k=1+3,322 x \log (n)
$$

Dimana k merupakan banyaknya kelas dan n merupakan banyaknya nilai observasi, sedangkan untuk Interval kelas tiap kategori didapatkan dengan meggunakan rumus sebagai berikut:

$$
c=\frac{X n-X 1}{k}
$$

Dimana c merupakan lebar kelas tiap kategori; k adalah banyaknya kelas; Xn merupakan nilai observasi terbesar dan X1 merupakan nilai observasi terkecil. Total pertanyaaan yang dibagikan 
kepada siswa berjumlah 10 pertanyaan dan untuk penilaian dibagi menjadi empat kategori yaitu tidak paham, kategori kurang paham, kategori paham dan kategori sangat paham. Hasil evaluasi pelaksanaan pengabdian dapat dilihat pada tabel berikut:

Tabel 1. Hasil evaluasi pelaksanaan pengabdian tentang telekomunikasi

\begin{tabular}{cccc}
\hline Kelas Interval & Kategori & pre-test & post-test \\
\hline $0=<\mathrm{x}<3$ & Tidak Paham & $35.82 \%$ & $13.33 \%$ \\
$3=<\mathrm{x}<5$ & Kurang Paham & $41.79 \%$ & $26.67 \%$ \\
$5=<\mathrm{x}<8$ & Paham & $22.38 \%$ & $46.67 \%$ \\
$8=<\mathrm{x}=<10$ & Sangat Paham & $0 \%$ & $13.33 \%$ \\
\hline
\end{tabular}

Dari gambar 4 menunjukkan bahwa setelah dilakukan pemaparan dan penjelasan pada pengabdian, jumlah siswa dengan kategori "tidak paham" mengalami penurunan $22.49 \%$ yaitu dari $35.82 \%$ menjadi $13.33 \%$. Jumlah siswa dengan kategori "kurang paham" mengalami penurunan $15.12 \%$ yaitu dari $41.8 \%$ menjadi $26.7 \%$. Untuk kategori "paham" mengalami kenaikan yang sangat drastis yaitu $24.29 \%$ yaitu dari $22.38 \%$ menjadi $46.67 \%$ sedangkan untuk kategori "sangat paham" mengalami kenaikan $13 \%$ dari $0 \%$ menjadi $13.33 \%$. Dari hasil analisa diatas dapat ditarik kesimpulan bahwa kegiatan pengabdian kepada masyarakat yang telah dilakukan memberikan efek dan pengetahuan yang baik kepada generasi muda khususnya siswa SMP Muhammadiyah 6 Palembangi.

\section{KESIMPULAN DAN SARAN}

Penggunaan internet telah digunakan oleh berbagai macam umur khususnya pada generasi muda siswa SMP Muhammadiyah 8 Palembang. Pada penelitian menunjukkan hasil yang cukup mengejutkan bahwa hampir seluruh siswa telah menggunakan Internet dengan berbagai penggunaan baik dalam penggunaan email, media sosial maupun social messanger. Pada sisi penggunaan email, hHampit 53\% siswa telah mempunyai akun email dan telah menggunakan email sebagai media pengiriman informasi dan $47 \%$ siswa belum memiliki aku email. Pada pengunaan social media hampir 90\% siswa telah memiliki dan menggunakan facebook, sekitar $51.67 \%$ siswa telah memiliki akun dan sudah menggunakan Instagram, dan hanya sekitar $3.33 \%$ atau hanya 3 siswa yang memiliki akun twitter. Untuk social messanger whatsapp, sekitar $26.67 \%$ telah menggunakan whatssapp, sekitar $21.67 \%$ telah menggunakan LINE sebagai media komunikasi dan sekitar 35\% yang telah menggunakan BBM sebagai media komunikasi. Dari sisi kegiatan yang dilakukan dapat disimpulkan bahwa terjadi peningkatan pemahanan pada siswa seelah diadakan kegiatan pengabdian yaitu siswa dengan kategori "tidak paham" mengalami penurunan yang signifikan yaitu sekitar $22.49 \%$. Untuk kategori siswa dengan kategori "kurang paham" juga mengalami penurunan dari $41.79 \%$ menjadi $15.12 \%$. Untuk kategori siswa yang paham mengalami peningkatan yang signifikan yaitu $24.29 \%$. Sedangkan untuk kategori siswa yang sangat paham mengalami kenaikan 13.33\%. Beberapa saran yang dapat diberikan untuk pengembangan dari kegiatan pengabdian ini yaitu materi yang diberikan dapat dikembangkan dalam hal efek baik dan buruknya perkembangan telekomunikasi ke depan ditinjau dari sisi psikologi. 


\section{DAFTAR PUSTAKA}

Admaja, A. F. S. 2018. Pemetaan Riset Teknologi 5G. Buletin Pos Dan Telekomunikasi, vol 16(1), hal 27-40

APJII. 2018. Penetrasi \& Profil Perilaku Pengguna Internet Indonesia Tahun 2018. Laporan Survei APJII 2018, Jakarta

Firdausi, A. (2019). Pengenalan Teknologi 5G (Generasi ke 5) pada Sebuah Sistem Antena Untuk Siwa/I SMA di Kembangan Utara Universitas Mercu Buana Jakarta Barat. Jurnal Abdi Masyarakat (JAM), vol 5(1), hal 6-10.

Kristem, V., Bas, C. U., \& Member, S. 2018. Outdoor Wideband Channel Measurements and Modeling in the 3-18 GHz Band. IEEE Transactions on Wireless Communications, vol 1276(c), hal 1-15.

Majed, M. B., Rahman, T. A., Aziz, O. A., Hindia, M. N., \& Hanafi, E. 2018. Channel characterization and path loss modeling in indoor environment at $4.5,28$, and $38 \mathrm{GHz}$ for $5 \mathrm{G}$ cellular networks. International Journal of Antennas and Propagation, 2018. vol 2018, hal $1-14$

Qualcomm. 2019. Global update on 5G spectrum. Qualcomm Report 2019, Hal 1-19. United States. 